\title{
FOOT PROBLEMS OF FEMALE MEDICAL PERSONNEL: SUBJECTIVE COMPLAINTS AND RESULTS OF THE PODOMETRIC TEST
}

\author{
Marija Avota*, Anita Raciborska**, and Andrejs Avots*** \\ * Department of Occupational and Environmental Medicine, Rīga Stradinš University, Dzirciema iela 16 Rīga, LV-1007, LATVIA \\ ** "Biḳernieki" Clinic, Riga Eastern Clinical University Hospital, Lielvārdes iela 68, LV-1006, Riga, LATVIA \\ *** Pirmaden Medical Centre Ltd., Bauskas iela 20, Rīga, LV-1004, LATVIA \\ E-mail: marija.avota@rsu.Iv
}

Communicated by Andrejs Skaǵers

The research was carried out in a multi-profile clinic where female medical workers included nurses, doctors and nurse assistants. The number of respondents included in the data analysis of this research was 102. A standardised questionnaire was used to obtain data on age group, position, body mass index, physical activities, ergonomic factors at work, performed objective foot examination methods, awareness of the ways of feet deformation correction. A computerised foot diagnostic system Pad Professional was used to objectively assess the feet condition. The podometric examination was carried out on 78 respondents. The data indicated a widespread foot problem spread among medical workers. Of 102 respondents only 10 (4.2\%) had no complaints, and of 78 respondents who underwent the podometric test, none were diagnosed as having a totally healthy foot. The podometric examination showed that 65 (83.3\%), which was the vast majority of respondents, had transverse arch flattening. Explicit transverse arch flattening was diagnosed in $8(10.3 \%)$ and longitudinal arch flattening in $5(6.4 \%)$ respondents.

Key words: female medical personnel, occupational factors, feet load, longitudinal arch flattening, transverse arch flattening.

\section{INTRODUCTION}

Medical personnel are subject to numerous risk factors at their work place: psycho-emotional and organisational, physical, chemical, biological, and ergonomic factors (Eglīte 2000; Avota u.c., 2001; Kaḷkis un Roja, 2001; Alexopoulos et al., 2006; Bos et al., 2007). One of the most important factors is the influence of the physical workload on person's support-movement apparatus. Excessive influence of these factors can lead to the damage to the support-movement apparatus.

Previous research carried out in different medical institutions of Latvia's regions found that the main health problem of respondents was considered to be damage to support-movement apparatus, which was suggested by different levels and intensity of pain in the back (Lācis, 2002). Epidemiological research carried out in Israel, on pain in the back and lumbar sacral region experienced by nurses and their assistants, showed that $78.5 \%$ of respondents had pain in the lumbar sacral region that had repeated during the last 12 months (Podniece, 2000). The main factors that determined the high occurrence included forced pose (surgeons, dentists), as well as moving heavy burdens, and lifting patients (nurses, nurse assistants). Foot deformations that influence the overall condition of the leg joints and spine have also been mentioned in the literature as one of the possible reasons for the spinal ache. Correctly developed feet shape good posture, which is one of the preconditions for good health (Шапошникова, 1997; Nordin and Frankel, 2001). Elasticity is necessary so that the body does not feel overload and stress during a walk or a run. Feet have elasticity due to their unique construction, which is kept fast by a system of ligaments and muscles. Also, pathological structures in shank and thigh diaphysis have been shown by incorrect load on lower limb in the case of feet deformation, as well as by wearing inappropriate footwear (Skḷarevičs, 2003; Logina, 2006).

The reasons for feet illnesses are very different, and frequently they are combined. Most of feet illnesses appear in later years of a lifetime, and most often their cause is wearing inappropriate footwear and lasting, excessive load on feet (Ombregt, 1995; Eglīte, 2000; Alexopoulos et al., 2006; Bos et al., 2007). Since 1999, analysis of the occupational diseases of patients in Latvia showed that there was rising morbidity from skeleton, muscle and conjunctive tissue illnesses. From 2000 to 2008, these illnesses ranked first among annual occupational diseases (34.8\%), which indicates persisting ergonomic risk factors in the work environment. While doing their work, medical personnel are 
subject to numerous risk factors, which can influence their health. Nurses, nurse assistants, and doctors have a job that involves standing and lifting and moving weights.

According to the definition given by the World Health Organisation, health is a state of complete physical, mental and social well-being and not merely the absence of disease or infirmity (Anonymous, 1948). A person operates under tight interaction of his internal (physical, psychic, mental) and external environment. He is a part of the external environment: he has an effect on the environment and the environment has the effect on him (Avota, 2001). The external environment consists of the place and conditions in which the person acts. There is continuous interaction between the environment and the person, which is why it is necessary to take into account the principles of ergonomics at the work place to minimise the effect of risk factors on the person. The aim of ergonomic methods is mutual adaptation between the environment and the person (Nordin and Frenkel, 2001).

It is important for nurses and nurse assistants to perform the care for the patients correctly, without traumatising themselves. To minimise the load on legs and spine, it is necessary to correctly lift and relocate patients and to use appropriate footwear when being on feet for a long time. The doctors who need to stay for a longer time in a forced pose, for example, during operation, also need to wear footwear that has been constructed correctly or to use an orthopaedic sole that divides the load on the whole foot, thereby eliminating the traumatising influence on knee and hip joints and spine. To be able to eliminate the possible risk factors, it is necessary to know the preventive measures.

The aim of this study was to determine the condition of their feet in female medical personnel, their awareness of the condition of their feet and possibilities of feet correction.

\section{MATERIALS AND METHODS}

The research involved female medical personnel at a multiprofile clinic: nurses, doctors, and nurse assistants. The number of respondents included in the data analysis was 102. The condition of their feet, awareness of it and the possibilities of the feet correction were determined by a standardised questionnaire. Questions were given on age group, position, BMI, physical activities, ergonomic factors at work, performed objective foot examination methods, and awareness about the ways of foot deformation corrections. A computerised foot diagnostic system Pad Professional was used to objectively assess the condition of the feet. Data were processed with the computer softwares SPSS for Windows and Excel. Descriptive statistics were used.

\section{RESULTS}

The data obtained indicates a widespread foot problem among the medical workers. Of 102 respondents, only ten (4.2\%) had no complaints, and of 78 who were given the podometric test, none were diagnosed as having a totally healthy foot. The main foot problem in female medical workers was transverse arch flattening. The podometric examination showed that the vast majority of respondents $65(83.3 \%)$ - had transverse arch flattening. Explicit transverse arch flattening was diagnosed in eight (10.3\%), and longitudinal arch flattening in five (6.4\%) respondents (Fig. 1).

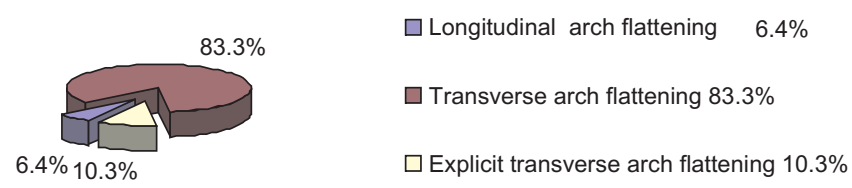

Fig.1. Podometry results of patients with arch flattening.

The knowledge of the participating medical workers about their feet was insufficient, since 94 (91.3\%) respondents previously had not been given any podometric test. Medical workers are not informed well enough about the possibilities of feet correction, but most of them -68 respondents $(54.0 \%)$ - admitted the significance of feet deformation correction, and $66(64.7 \%)$ correctly described the features of instep-raiser impact. Regarding awareness of the optimal height of the shoe heel, $68(66.7 \%)$ recorded the correct version, although the respondents themselves at home 90 $(87.6 \%)$ and at work $58(56.8 \%)$, where there is a greater amount of load on feet, wear footwear with improper height of heel.

Comparing subjective complaints and the results acquired in the podometric test, it was ascertained that 39 (28.5\%) respondents have leg tiredness. Among the respondents, 23 (16.8\%) mentioned deformation of fingers and emergence of "ossicle", $20(14.6 \%)$ also observed thickening of skin on feet under II, III, IV fingers, and $18(13.1 \%)$ complained about pain at the front part of the foot. All these complaints are characteristic of flatfoot of the transverse arch at its I II stage. The subjective complaints (Fig. 2) of the study group conformed to the results obtained in the podometric test.

Regarding the load on the longitudinal arch (Table 1), of 65 respondents with transverse arch flattening, 54 (83.0\%) had unladen, and eight $(12.3 \%)$ had partial load on the longitudinal arch. Only three (4.6\%) had loaded longitudinal arch. Of the eight respondents with explicit transverse arch flat-

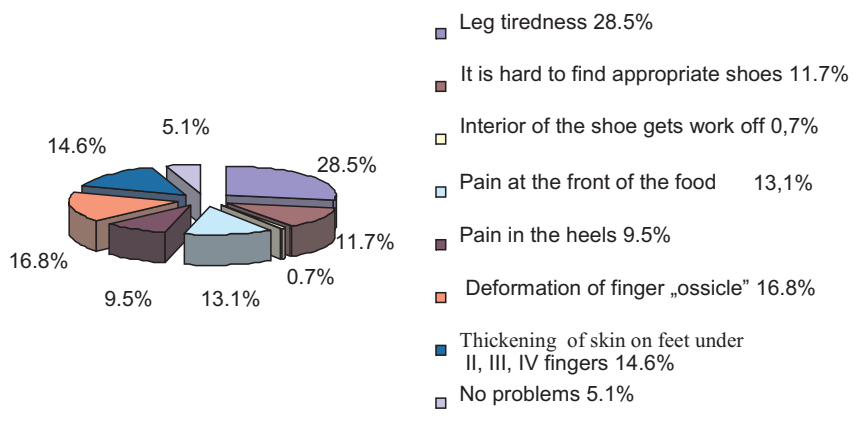

Fig. 2. Subjective complains in cases when transversal arch is overstressed. 
Table 1

LONGITUDINAL ARCH FLATTENING RESULTS IN FEMALE MEDICAL WORKERS

\begin{tabular}{|c|c|c|c|c|}
\hline \multirow[t]{2}{*}{ Podometry results } & \multirow[t]{2}{*}{$\mathrm{n}$} & \multicolumn{3}{|c|}{ Longitudinal arch } \\
\hline & & unladen & loaded & partly loaded \\
\hline $\begin{array}{l}\text { Longitudinal arch } \\
\text { flattening }\end{array}$ & 5 & $0(0 \%)$ & $5(100 \%)$ & $0(0 \%)$ \\
\hline $\begin{array}{l}\text { Transverse arch } \\
\text { flattening }\end{array}$ & 65 & $54(83.0 \%)$ & $3(4.6 \%)$ & $8(12.3 \%)$ \\
\hline $\begin{array}{l}\text { Explicit transverse } \\
\text { arch flattening }\end{array}$ & 8 & $5(62.5 \%)$ & $2(25.0 \%)$ & $1(12.5 \%)$ \\
\hline Total & 78 & $59(75.64 \%)$ & $10(12.82 \%)$ & $9(11.54 \%)$ \\
\hline
\end{tabular}

tening, five $(62.5 \%)$ had unladen longitudinal arch, two (25\%) had loaded longitudinal arch, and one (12.5\%) had partly loaded longitudinal arch. Flattening of loaded longitudinal arch was detected in five respondents. The results obtained are similar to the data in the literature. Transverse arch flattening with unladen longitudinal arch was a prevailing diagnosis.

As the development of flatfoot is associated with body mass, its increase, length of service and age, this was considered in the questionnaire information. Body mass and height were used to evaluate body mass index (BMI). Thirty-two $(41.0 \%)$ respondents had normal BMI, 27 (34.6\%) were overweight, and 19 (24.4\%) had obesity. Transverse arch flattening was observed in 27 (41.5\%) respondents with normal BMI, 22 (33.8\%) overweight respondents and 16 (24.6\%) obese respondents (Table 2). Explicit transverse arch flattening and longitudinal arch is more uncommon. When analysing BMI by groups, no statistically significant differences were found in BMI fluctuations as confidence interval was overlapping in all three groups.

Table 2

BODY MASS INDEX (BMI) IN RELATION TO PODOMETRY RESULTS IN FEMALE MEDICAL WORKERS

\begin{tabular}{l|c|c|c|c}
\hline Podometry results & $\mathrm{n}$ & \multicolumn{3}{|c}{ BMI group } \\
\cline { 3 - 5 } & & normal & overweight & obesity \\
\hline $\begin{array}{l}\text { Longitudinal arch } \\
\text { flattening }\end{array}$ & 5 & $1(20.0 \%)$ & $3(60.0 \%)$ & $1(20.0 \%)$ \\
$\begin{array}{l}\text { Transverse arch } \\
\text { flattening }\end{array}$ & 65 & $27(41.5 \%)$ & $22(33.8 \%)$ & $16(24.6 \%)$ \\
$\begin{array}{l}\text { Explicit transverse } \\
\text { arch flattening }\end{array}$ & 8 & $4(50.0 \%)$ & $2(25.0 \%)$ & $2(25.0 \%)$ \\
Total & 78 & $32(41.0 \%)$ & $27(34.6 \%)$ & $19(24.4 \%)$
\end{tabular}

The podometric research was carried out on 78 respondents, of which $36(46.2 \%)$ were nurses, 24 (30.8\%) nurse assistants, and $18(23.0 \%)$ were doctors. Comparing the results of podometric test and data obtained in the questionnaires, transverse arch flattening was observed in $30(46.2 \%)$ nurses, $19(29.2 \%)$ nurse assistants, and $16(24.6 \%)$ doctors, and there were no significant differences between the groups (Table 3). Regarding length of service, 29 (37.2\%) respondents had worked 31 years and longer; $21-30$ years of service in medicine were marked by $18(23.1 \%)$ respondents; the same amount marked 5-10 and 11-20 years of service; only five (6.4\%) respondents indicated their length of service as less than five years. Comparing the length of service and podometric data (Table 4), the greatest problems were found in workers with 31 years of service or longer, as 20 of 29 respondents had diagnosed transverse arch flattening, five had explicit transverse arch flattening, and four had flattening of longitudinal arch. Thus, problems with feet were present in all service length groups, but were greater with 31 years of service or more.

The data were also examined among age groups: 20 to 29 years $(\mathrm{n}=3,3.8 \%)$; 30 to $39(\mathrm{n}=18,23.1 \%) ; 50$ to $59(\mathrm{n}=$ $28,35.9 \%) ; 60$ or more years $(n=13,16.7 \%)$. The comparison between the age groups and podometric data is shown in Table 5.

Transverse arch flattening was common in all age groups, although after the age of 60 explicit transverse arch flattening increased. There were no significant differences between transverse arch flattening with age, but proportional explicit transverse arch flattening cases increased. Answering to a question about possible feet deformations, 30 (36.1\%) responded that feet were healthy and $16(19.3 \%)$ did not know about their feet problems. High instep was

Table 3

MEDICAL DUTY IN RELATION TO PODOMETRY RESULTS IN FEMALE MEDICAL WORKERS

\begin{tabular}{l|c|c|c|c}
\hline \multirow{2}{*}{ Podometry results } & $\mathrm{n}$ & \multicolumn{3}{|c}{ Medical duty } \\
\cline { 3 - 5 } & & nurses & $\begin{array}{c}\text { nurse assis- } \\
\text { tants }\end{array}$ & doctors \\
\hline $\begin{array}{l}\text { Longitudinal arch } \\
\text { flattening }\end{array}$ & 5 & $3(60.0 \%)$ & $2(40.0 \%)$ & $0(0 \%)$ \\
$\begin{array}{l}\text { Transverse arch flat- } \\
\text { tening }\end{array}$ & 65 & $30(46.2 \%)$ & $19(29.2 \%)$ & $16(24.6 \%)$ \\
$\begin{array}{l}\text { Explicit transverse } \\
\text { arch flattening }\end{array}$ & 8 & $3(37.5 \%)$ & $3(37.5 \%)$ & $2(25.0 \%)$ \\
$\begin{array}{l}\text { Total } \\
\end{array}$ & 78 & $36(46.2 \%)$ & $24(30.8 \%)$ & $18(23.1 \%)$
\end{tabular}

WORK EXPERIENCE IN RELATION TO PODOMETRY RESULTS IN FEMALE MEDICAL WORKERS

\begin{tabular}{|c|c|c|c|c|c|c|}
\hline \multirow[t]{2}{*}{ Podometry results } & \multirow[t]{2}{*}{$\mathrm{n}$} & \multicolumn{5}{|c|}{ Work experience (years) } \\
\hline & & until 5 & $5-10$ & $11-20$ & $21-30$ & 31 and more \\
\hline Longitudinal arch flattening & 5 & $0(0 \%)$ & $0(0 \%)$ & $1(20.0 \%)$ & $0(0 \%)$ & $4(80.0 \%)$ \\
\hline Explicit transverse arch flattening & 8 & $1(12.5 \%)$ & $2(25.0 \%)$ & $0(0 \%)$ & $0(0 \%)$ & $5(62.5 \%)$ \\
\hline Total & 78 & $5(6.4 \%)$ & $13(16.7 \%)$ & $13(16.7 \%)$ & $18(23.1 \%)$ & $29(37.2 \%)$ \\
\hline
\end{tabular}


AGE IN RELATION TO PODOMETRY RESULTS IN FEMALE MEDICAL WORKERS

\begin{tabular}{|c|c|c|c|c|c|c|}
\hline \multirow[t]{2}{*}{ Podometry results } & \multirow[t]{2}{*}{$\mathrm{n}$} & \multicolumn{5}{|c|}{ Age (years) } \\
\hline & & $0-19$ & $20-39$ & $40-49$ & $50-59$ & 60 and more \\
\hline Longitudinal arch flattening & 5 & $0(0 \%)$ & $1(20 \%)$ & $0(0 \%)$ & $2(40 \%)$ & $2(40 \%)$ \\
\hline Transverse arch flattening & 65 & $2(3.1 \%)$ & $14(21.5 \%)$ & $18(27.7 \%)$ & $24(36.9 \%)$ & $7(10.8 \%)$ \\
\hline Explicit transverse arch flattening & 8 & $1(12.5 \%)$ & $1(12.5 \%)$ & $0(0 \%)$ & $2(25.0 \%)$ & $4(50.0 \%)$ \\
\hline Total & 78 & $3(3.8 \%)$ & $1620.5(\%)$ & $18(23.1 \%)$ & $28(35.9 \%)$ & $13(16.7 \%)$ \\
\hline
\end{tabular}

mentioned by $16(19.3 \%)$ respondents and flatfoot by ten $(12.0 \%)$. Of ten respondents who indicated flatfoot, eight had transverse arch flattening and two had explicit transverse arch flattening. Of 11 respondents who indicated that they had hallux valgus, ten had transverse arch flattening and one had explicit transverse arch flattening. Thirty respondents denied having feet problems, but the podometric data showed 26 to have transverse arch flattening, and four had explicit transverse arch flattening. High instep was indicated by 16 respondents; of them 14 had transverse arch flattening and two had flattening of longitudinal arch. Sixteen respondents had no idea about their feet problems, but the podometric test showed 11 respondents to have transverse arch flattening, two had explicit transverse arch flattening, and three had flattening of longitudinal arch. The awareness of respondents about the condition of their feet was insufficient, as those who did not indicate any feet problems did not know about the deformations of their feet, but podometric tests showed transverse arch flattening, as well as explicit transverse arch flattening.

\section{DISCUSSION}

The aim of the work was to determine the condition of feet of medical workers and their awareness about this and about the possibilities of corrections, and this was achieved by examining the effect on foot by ergonomic risk factors at work, BMI, length of service and age, at a multi-profile clinic. The literature describes weight to be associated with feet problems for women (Lācis, 2002). Our study included only women, and further studies should include also men. The characteristic feet problems for female medical workers in literature are similar with our results. Problems of arch flattening were typical for female medical workers and the obtained data are similar to descriptions in the literature (Alexopoulos et al., 2006; Bos et al., 2007). Of 78 respondents, $65(84.0 \%)$ had transverse arch flattening and eight $(10.3 \%)$ had explicit transverse arch flattening. The results indicate widespread foot problem among medical workers. To confirm the data obtained in the research, similar studies should be carried out in other clinics (Podniece, 2001; Alexopoulos et al., 2006; Bos et al., 2007).

We observed that, of 102 respondents, only ten $(4.2 \%)$ did not have any complaints, and of 78 respondents who were involved in the podometric test, none were diagnosed with absolutely healthy feet. The awareness of medical workers about the condition of their feet was insufficient, as
$94(91.3 \%)$ respondents had never had any podometric tests. Medical workers are not informed well enough about the possibilities of feet correction, but most of them - 68 $(54.0 \%)$ - admit the significance of foot deformation correction, and $66(64.7 \%)$ named correctly the impact of an instep-raiser. Regarding the optimal height of the shoe heel, $68(66.7 \%)$ marked the correct version, although the respondents wear, at home $90(87.6 \%)$ and at work 58 (56.8\%), where there is greater load on feet, footwear with improper height of heel. To explore the direct effect of load on the flattening of foot, it would be valuable to perform studies to diagnose the condition of feet in personnel from different medical professions, e.g., to surgeons before and after they have performed a surgery. Although we found widespread feet problems among medical workers obtained through questionnaires and podometric tests, this cannot be applied to all medical workers, as respondents of this research were only women and they all worked in the same clinic.

The conclusions are:

1. The data obtained in the research show an important foot problem among female medical workers.

2. None of the respondents had a healthy foot, the most characteristic problem was transverse arch flattening with unladen longitudinal arch.

3. The awareness of medical workers about their feet problems was insufficient, $91.3 \%$ respondents had never used any of the objective feet examination methods.

4. There was also not enough attention paid to prevention of feet problems — orthopaedic footwear, instep-raisers are practically not used at work.

5. The research affirms the hypothesis that ergonomic risk factors influence female medical workers (standing for a longer time in a forced pose, reiterative lifting and moving of heavy weights).

6. Body mass was not found to be associated with feet problems in this research.

\section{REFERENCES}

Anonymous (1948). Constitution of the World Health Organization. Preamble. Official Records of the World Health Organization, No. 2, p. 100.

Alexopoulos, E.C., Burdorf, A., Kalokerinou, A. (2006). A comparative analysis on musculoskeletal disorders between Greek and Dutch nursing personnel. J. Int. Arch. Occup. Environ. Health, 79(1), 82-83. 
Avota, M., Eglīte, M., Matisāne, L. (2001). Medicīnas darbinieku saslimstība un tās saistība ar darba vides kaitīgajiem faktoriem — Latvijas pieredze [Medical employees morbidity rate and its relationship with the harmful factors of work place environment - Latvian experience]. Grām.: Ceturtā Pasaules Latviešu ārstu kongresa tēzes (38.-39. lpp.). Rīga (in Latvian).

Bos, E., Krol, B., van der Star, L., Groothoff, J. (2007). Risk factors and musculoskeletal complaints in non-specialized nurses. IC nurses, operation room nurses, and X-ray tecnologists. J. Arch. Occup. Environ. Health, 80(3) 198-206.

Eglīte, M. (2000). Darba medicīna [Occupational Medicine]. Rīga. 701 lpp. (530.-531. lpp.) (in Latvian).

Kaḷkis, V., Roja, Ž. (2001) Darba vides riska faktori un strādājošo veselības aizsardzība. [Risk Factors of Working Place Environment and Employees Health Protection]. Rīga: Elpa. 500 lpp. (413.-416. lpp.) (in Latvian).

Lācis, A. (2002). Ilgais ceḷ̌s no gūžas locītavas līdz pēdai [A long way from hip joint to foot]. Latvijas Ārstu Žurnāls, Nr. 3, 6-12 (in Latvian).

Logina, I. (2006). Muguras sāpes [Back Pains]. Rīga: SIA Nacionālais apgāds. 368 lpp. (174.-175., 230.-245. 1pp.) (in Latvian).

Received 19 June 2009
Nordin, M., Frankel, V.H. (eds.) (2001). Basic Biomechanics of the Musculoskeletal System. $3^{\text {rd }}$ edn. Philadelphia: Lippincott Williams \& Wilkins. 484 pp. (pp. 222-255, 467).

Ombregt, L., Bisschop, P., ter Veer, H.J., Van de Velde, T. (1995). A System of Ortopaedic Medicine. London: WB Saunders Company Ltd. (pp. 847-856).

Podniece, Z. (2000). Epidemioloǵisks pētījums par muguras jostas un krustu daḷas sāpēm medmāsām un to palīdzēm [Epidemiological research of nurses and their assistants' backpain]. Grām.: RSU Zinātniskie raksti (139.-142. 1pp.). Rīga (in Latvian).

Skḷarevičs, V. (2003). Pēdas garenvelves augstuma izmainas ietekmējošie faktori pirmsskolas vecuma bērniem. Promocijas darba kopsavilkums [Essential factors of feet longitudinal arch changes in primary school kids. Abstract of Doctoral thesis]. Rīga. 38 lpp. (in Latvian).

Авота М.А., Эглите М.Э., Матисане Л.В., Екабсоне И.А. (2002). Объективные и субъективные данные о профессиональных заболеваниях медицинских работников Латвии [Objective and subjective facts of medical employees of occupational diseases in Latvia]. Медицина труда и промышленная экология, № 3, 33-37 (in Russian).

Шапошникова И.Г. (1997) Травматология и ортопедия. Руководство для врачей. Патология нижних конечностей. Том 3 [Traumatology and Orthopaedy. Manual for doctors. Pathology of Extremities. Vol. 3] (230-356 с.). Москва: Медицина, 624 с. (in Russian).

\section{PĒDU PROBLĒMAS MEDICĪNAS DARBINIECĒM: SUBJEKTĪVĀS SŪDZĪBAS UN PODOMETRIJAS DATI}

Pētījums veikts daudzprofilu klīnikā, tajā iesaistìtas medicīnas darbinieces - māsas, ārstes un māsu palīdzes. Pētījuma datu analīzē iekḷauto respondenšu skaits bija 102. Kā pētījuma instruments izmantota standartizēta anketa, tika analizēti jautājumi, kuros iegūta informācija par vecuma grupu, amatu, ķermeņa masas indeksu, fiziskām aktivitātēm, ergonomiskiem faktoriem darbā, veiktām objektīvām pēdu izmeklēšanas metodēm, informētību par pēdu deformāciju korekcijas veidiem. Lai objektīvi novērtētu pēdas stāvokli, tika izmantota datorizētā pēdu diagnostikas sistēma Pad Professional. Podometrijas izmeklējums tika veikts 78 respondentēm. Pētniecības darba gaitā iegūtie dati liecina par pēdu problēmu izplatîbu medicīnas darbinieču vidū: no 102 respondentēm sūdzības nebija tikai 10 (4,2\%), no 78 podometrijā iesaistītiem respondentēm nevienai netika konstatēta pilnīgi vesela pēda. Podometrijas izmeklēšanas laikā tika konstatēts, ka 65 (83,3\%), tātad lielākai daḷai respondenšu, ir šḳērsvelves saplacināšanās. Izteikta šḳērsvelves saplacināšanās ir astoṇām (10,3\%), un piecām $(6,4 \%)$ respondentēm ir garenvelves saplacināšanās. 